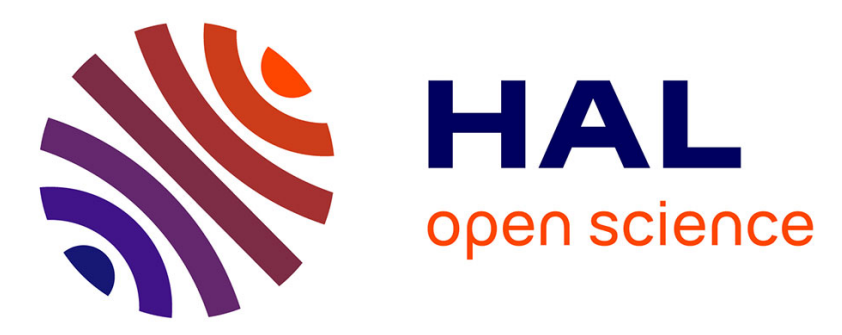

\title{
Diagenetic history of Triassic sandstone from the Beacon Supergroup in central Victoria Land, Antarctica.
}

\author{
Matthias Bernet, Reinhard Gaupp
}

\section{To cite this version:}

Matthias Bernet, Reinhard Gaupp. Diagenetic history of Triassic sandstone from the Beacon Supergroup in central Victoria Land, Antarctica.. New Zealand Journal of Geology and Geophysics, 2005, 48, pp.447-458. hal-00097126

\section{HAL Id: hal-00097126 \\ https://hal.science/hal-00097126}

Submitted on 21 Sep 2006

HAL is a multi-disciplinary open access archive for the deposit and dissemination of scientific research documents, whether they are published or not. The documents may come from teaching and research institutions in France or abroad, or from public or private research centers.
L'archive ouverte pluridisciplinaire HAL, est destinée au dépôt et à la diffusion de documents scientifiques de niveau recherche, publiés ou non, émanant des établissements d'enseignement et de recherche français ou étrangers, des laboratoires publics ou privés. 


\title{
Running head: Diagenesis of Beacon Sandstone
}

\section{Diagenetic history of Triassic sandstone from the Beacon Supergroup in central Victoria Land, Antarctica}

\author{
MATTHIAS BERNET* and REINHARD GAUPP** \\ Institut für Geowissenschaften, \\ Johannes-Gutenberg Universität \\ Mainz, Germany \\ ${ }^{*}$ Corresponding author, present address: State University of New York, New Paltz, USA \\ Email:matthias.bernet@aya.yale.edu \\ **Present address: Institut für Geowissenschaften, \\ Friedrich Schiller Universität, Jena, Germany
}

Abstract The diagenetic history of Triassic sandstone from the Beacon Supergroup, Victoria Land, Antarctica, can be divided into three main phases of shallow burial diagenesis, contact diagenesis (temperatures of $200-300^{\circ} \mathrm{C}$ ), and post-contact diagenesis, on the basis of petrographic and geochemical analyses. Shallow burial diagenesis is characterised by minor compaction, K-feldspar alteration to illite, and quartz cementation. Contact diagenesis is related to emplacement of dolerite intrusions and basalt flows during Gondwana break-up at $180 \mathrm{Ma}$. This high-temperature diagenetic phase is dominated by zeolite cementation, even in sandstone poor in zeolite precursor materials. Elevated thermal conditions associated with the igneous intrusions are suggested by increased illite crystallinity, but strong evidence for contact metamorphism is missing. Post-contact diagenesis is signified by zeolite and Kfeldspar dissolution, and local quartz, calcite cementation and minor albite and K-feldspar precipitation. This diagenetic phase is possibly related to renewed (hydro-) thermal activity in Victoria Land in association with rifting of New Zealand and Australia from Antarctica at c. 96 Ma. 
Keywords contact diagenesis; zeolite cementation; dolerite intrusion; Beacon Supergroup; Antarctica

\section{INTRODUCTION}

The order in which framework grains are altered and authigenic phases are precipitated and perhaps subsequently dissolved, can be analyzed to reveal the post-depositional history of siliciclastic sedimentary rocks. Of particular interest is the destruction of primary porosity by compaction and cementation, and creation of secondary porosity by dissolution of framework grains and/or authigenic mineral phases. Porosity is important for aquifer and reservoir qualities of sandstone. If compaction is not the main cause of porosity reduction, then quartz, calcite, and dolomite cementation or clay mineral formation are usually the most important factors for reducing primary porosity in sandstone under regular diagenetic conditions (c. 0$150^{\circ} \mathrm{C}$, c. $\left.0-1 \mathrm{kbar}\right)$. However, quartz, calcite, etc. are not the only authigenic minerals that can pervasively fill pore space. Precipitation of zeolite cement can cause extensive cementation and has been reported to occur in volcaniclastic sandstone by alteration of volcanic rock fragments, including volcanic glass, and plagioclase (Boles \& Coombs 1975, 1977; Remy 1994). In addition, zeolite cementation is also known to occur under contact metamorphic conditions in connection to intrusions of igneous rocks (Kroiting 1978; Brauckmann \& Füchtbauer 1983).

McKinely et al. (2001) presented a study on the effect of an intrusion on the reservoir quality of the Triassic Sherwood Sandstone group. These authors defined the term contact diagenesis to describe the paragenetic changes that occurred associated with the intrusion, because no clear indications for full contact-metamorphic conditions were found. McKinely 
et al. (2001) concluded that the total porosity and permeability of the Sherwood Sandstone remained basically unaffected by the intrusion and contact diagenesis.

We present here a study of a similar setting, with samples from sandstone of the Triassic part of the siliciclastic Beacon Supergroup in central Victoria Land, Antarctica, which had been intruded by massive dolerite sills and dikes at c. 180 Ma (Gunn \& Warren 1962; Ballance \& Watters 2002). Comparable to the Sherwood Sandstone the Beacon Sandstone units do not show any macroscopic evidence for contact metamorphism. Consequently, to see if the Beacon Sandstone responded in a similar way to contact diagenesis as the Sherwood Sandstone did, the purpose of this study was to reconstruct the diagenetic history of the Beacon Sandstone. We were particularly interested in finding evidence for the destruction and creation of porosity, and the thermal overprint caused by the dolerite intrusions. We performed petrographic and geochemical analyses on 17 samples from 4 different outcrops at Trio Nunatak, McLea Nunatak, Thumb Point, and Shultz Peak in central Victoria Land (Fig. 1, Table 1), which are representative for the Beacon Supergroup at least on a local scale.

\section{GEOLOGICAL SETTING}

Victoria Land is part of the Transantarctic Mountains, which stretch for $>3000 \mathrm{~km}$ from North Victoria Land along the Ross Sea to Coats Land near the Weddell Sea, along the western margin of the East Antarctic shield (Fig. 1). The crystalline basement in Victoria Land, consisting of Precambrian metamorphic and Paleozoic granitic rocks, was deeply eroded during and after the Ross orogeny (c. $500 \mathrm{Ma}$ ) and is now unconformably overlain by sedimentary and igneous rocks of the Gondwana series. The Gondwana series is commonly subdivided into the Devonian-Triassic siliciclastic Beacon Supergroup and the Jurassic intrusive and effusive igneous Ferrar Group consisting of Ferrar Dolerite dikes and sills and Kirkpatrick Basalt flows (Barrett 1972, 1991; Collinson \& Pennington 1986). 
The c. $2.5 \mathrm{~km}$ thick Beacon Supergroup is further subdivided into the Taylor Group and Victoria Group (Fig. 2). The Taylor Group, with a maximum thickness of $1.1 \mathrm{~km}$, consists mainly of Devonian quartz arenites with characteristic thin red-beds at the base, middle, and top of the sequence, which indicate semi-arid to arid climatic conditions during deposition (Barrett 1972, 1991). The depositional environment of the Taylor Group evolved from an original marine setting to a fluvial-lacustrine setting further up-section. An unconformity separates the Taylor Group from the Permian-Triassic Victoria Group, with Carboniferous sediments missing in most of Victoria Land.

The oldest member of the Victoria Group begins with glacial deposits of the Metschel Tillite at its base, followed by the Weller Coal Measures, indicating a large scale climatic change at the Carboniferous/Permian boundary from glacial conditions to a warmer climate (Fig. 2). Overall, the depositional environments of the Permian-Triassic sediments are continental fluvial settings, and sandstone of this part of the Beacon Supergroup is commonly light coloured, medium to coarse grained, and cross-bedded (Barrett 1972, 1991; Collinson \& Pennington 1986). The amount of volcaniclastic fragments increases towards the top of the section, deposited during the Triassic.

The main lithologies of the Jurassic Ferrar Group found along the Transantarctic Mountains are continental flood basalts of doleritic and basaltic composition (Wilson 1989; Wilhelm 1994). Emplacement of these flood basalts, which are associated with the break-up of Gondwana, occurred c. 20 m.y. after accumulation of the Beacon Supergroup terminated (Ballance \& Watters 2002). The age of the basalt flows is $180.4 \pm 2.1 \mathrm{Ma}$ (Foland et al. 1993), while some sills were dated at $176.6 \pm 1.8 \mathrm{Ma}$ (Fleming et al. 1997). Thicknesses of basalt flows and sills are variable throughout Victoria Land, but reach up to $2000 \mathrm{~m}$. Some ephemeral fluvial and lacustrine sediments and weathering horizons of Jurassic age can be found between different flows. Hydrothermal activity was detected in the upper part of the 
Ferrar Group in North Victoria Land (Kirkpatrick Basalts) at $96 \pm 1 \mathrm{Ma}$, on the basis of $\mathrm{Ar} / \mathrm{Ar}$ and $\mathrm{Rb} / \mathrm{Sr}$ dating of apophyllite in basalt (Fleming et al. 1993; Mohlzahn et al. 1999). Such hydrothermal activity could be linked to the separation of New Zealand and Australia from Antarctica, starting c. 96 Ma. Another indication for Cretaceous thermal activity is the occurrence of small post-Jurassic andesite dikes in Victoria Land, which crosscut through Beacon Supergroup sedimentary rocks and Ferrar Group igneous rocks (Wilhelm 1994).

Uplift and erosion of the Transantarctic Mountains started between 45 and 50 Ma along the North-South striking Ross Sea Fault Zone. Using apatite fission-track ages, Fitzgerald (1992) determined uplift rates c. $0.1 \mathrm{~km} / \mathrm{m} . \mathrm{y}$., resulting in $6 \mathrm{~km}$ total uplift accompanied by 4.5-5 $\mathrm{km}$ of erosion in some parts of the Transantarctic Mountains. Because of this substantial erosion, it is not possible to determine precisely the maximum burial depths of Beacon Supergroup sandstone, but Vavra et al. (1979) estimate 600-2000 m burial depth for Triassic sediments in the central Transantarctic Mountains.

\section{SAMPLE LOCATIONS AND SAMPLING STRATEGY}

A research team of the Johannes-Gutenberg University (Mainz, Germany) and the BGR (Bundesanstalt für Geowissenschaften und Rohstoffe, Hannover, Germany) conducted reconnaissance fieldwork in Victoria Land in1992. Even though the fieldwork was primarily focused on Ferrar Group igneous rocks, seventeen Beacon Sandstone samples from 4 different outcrops in central Victoria Land were collected for this study. All 4 outcrops at Trio Nunatak, McLea Nunatak, Thumb Point, and Shultz Peak (Fig. 1) belong stratigraphically to the Triassic part of the Victoria Group (Fig. 2). However, it is not possible to give a more detailed stratigraphic position because of the lack of fossil material or specific key horizons. Furthermore, the stratigraphic relation between the different outcrops is not known because of poor exposure and vast ice coverage of areas between the outcrops. 
The sampling strategy was to take samples in direct contact with the dolerite intrusions and with increasing distances to them, to determine possible contact metamorphism and associated mineralogical changes in the Beacon Supergroup. This sampling strategy was possible at Trio Nunatak, McLea Nunatak, and Thumb Point (Table 1). The outcrop at Trio Nunatak consists of a 90-100 m high wall of light grey, mainly medium grained sandstone, which was intruded by several dolerite sills, each up to $10 \mathrm{~m}$ thick. Samples were collected in the lower part of this outcrop, below the lowest dolerite sill (Table 1). At McLea Nunatak a c. $40 \mathrm{~m}$ thick slice of mainly white to light brown, medium to coarse grained Beacon Sandstone is sandwiched between two dolerite sills of unknown original thickness (because of erosion of the top sill and burial of the bottom sill). Samples were collected from the top to the base of this outcrop between the sills. At Thumb Point the $30 \mathrm{~m}$ thick outcrop of Beacon Sandstone is overlain by a c. $100 \mathrm{~m}$ thick dolerite sill. In this location the Beacon Sandstone is commonly dark grey to grey-green and fine to medium grained. Samples were taken in contact to the overlying sill and at various vertical distances from there. One sample (TPB04) was collected in contact with a post-Jurassic andesite dike. The outcrop at Shultz Peak was very small and provided only one white, very well sorted, fine grained quartz arenite sample. The spatial relation between sandstone and dolerite intrusions is not known in this location. None of the samples collected for this study showed any signs of recent chemical weathering, as we would expected because of very low temperatures in this antarctic setting.

\section{METHODS}

Thirty thin sections (for 13 samples two thin sections) were analysed using a standard Leitz Orthoplan polarising microscope for petrographic and modal analysis. For sandstone classification, 300-400 points were counted per thin section using traditional point-counting techniques. 
The chemical composition of authigenic minerals, particularly of pore filling cement and clay minerals, was determined using a JEOL JXA 8900 RL electron microprobe (EMP), which was also used to obtain back-scatter electron and cathodoluminescence (CL) images. Highly polished, carbon coated thin-sections were used for these analyses. Point and line analyses were performed at $15.0 \mathrm{kV}$ acceleration voltage and 10-12 $\mathrm{nA}$ beam current using wavelength dispersive (WDS) quantitative analyses of the major elements: $\mathrm{Si}, \mathrm{Ti}, \mathrm{Al}, \mathrm{Cr}, \mathrm{Fe}$, $\mathrm{Mg}, \mathrm{Mn}, \mathrm{Ca}, \mathrm{Na}$, and $\mathrm{K}$. These analyses were done by sequential measurements with five different spectrometers, and automatically corrected using Phi-Rho-Z, XPP, ZAF and BenceAlbee correction methods (for details see Reed 1997). K-alpha line calibration was done prior to analysis using the following standards: wollastonite for $\mathrm{Si}$ and $\mathrm{Ca}, \mathrm{Al}_{2} \mathrm{O}_{3}$ for $\mathrm{Al}$, albite for $\mathrm{Na}, \mathrm{MgO}$ for $\mathrm{Mg}$, orthoclase for $\mathrm{K}, \mathrm{MnTiO}_{3}$ for $\mathrm{Mn}$ and $\mathrm{Ti}, \mathrm{Cr}_{2} \mathrm{O}_{3}$ for $\mathrm{Cr}$, and $\mathrm{Fe}_{2} \mathrm{O}_{3}$ for $\mathrm{Fe}$. Point analyses had an average duration of $2 \mathrm{~min}$, while line analyses were dependant on length. Energy dispersive analysis was only used for rapid identification of chemical phases and orientation on the sample.

For better visualisation of authigenic grain coatings and mineral replacements, additional images were taken on selected samples at $20 \mathrm{kV}$ acceleration voltage and $1 \mathrm{nA}$ beam current, using a CamScan CS44 scanning electron microscope (SEM) at the University of Stuttgart. Thin section samples were carbon coated, while rock fragment samples were gold-coated prior to SEM analysis. Chemical analyses with the SEM were restricted to EDS analysis for quick mineral identification.

Mineral identification in all samples was also supported by X-ray diffraction (XRD) analysis, performed with a Seibert XRD $3000 \mathrm{TT}\left(\mathrm{Cu} \mathrm{K \alpha}, 30 \mathrm{~mA}, 40 \mathrm{kV}, 3^{\circ}-70^{\circ} 2\right.$-theta). A $<63 \mu \mathrm{m}$ powder sample was measured for whole rock analysis for all sandstone samples. For this analysis samples were crushed, carbonate material removed with $5 \% \mathrm{CH}_{3} \mathrm{COOH}$, pulverised, and sieved to remove size artefacts. Clay mineral identification was done for 
selected samples on $\mathrm{a}<2 \mu \mathrm{m}$ fraction that was separated from the $<63 \mu \mathrm{m}$ fraction using the Atterberg technique. XRD results of some samples from Trio Nunatak and Thumb Point, which possessed illite but not smectite in their XRD analyses, were used to estimate illite crystallinity as an indicator of thermal conditions, using the Weber and Weaver indices.

The Weber-index is given by

$$
\mathrm{Hw}_{(\mathrm{rel})}=\left(\mathrm{Hw}_{(001)} \text { illite } / \mathrm{Hw}_{(100)} \text { quartz }\right)^{*} 100
$$

where $\mathrm{Hw}_{(\mathrm{rel})}$ is the relative half width value, $\mathrm{Hw}_{(001)}$ illite the width of the illite $(001)$ peak at half its height, and $\mathrm{Hw}_{(100)}$ quartz the width of the quartz ${ }_{(100)}$ peak at half its height (see Weber 1972 for details). $\mathrm{Hw}_{(\mathrm{rel})}$ values of $350-500$ indicate the boundary range between diagenesis and metamorphism, while values of $<120$ are a sign of metamorphic conditions. The Weaverindex sets the height of the illite XRD peak at $10 \AA$ in relation to that at $10.5 \AA$ (after Weaver 1960). Values of $<2.0$ show no indication of metamorphism, while values $>6.0$ imply fully metamorphic conditions.

\section{RESULTS}

\section{Petrography}

Petrographic analysis and standard point counting shows that Victoria Group sandstones are mainly sub-arkosic to sub-litharenitic in composition (Fig. 3A). Certain petrographic parameters such as mean grain size, sorting, normalised QFL data, percentages of clasts, cement, and porosity are summarised in Table 1 . The following general observations apply to framework grains. (1) Almost all quartz grains are monocrystalline and show microcracks and healed fractures in panchromatic CL analysis, which is typical for plutonic quartz (e.g., Sprunt \& Nur 1979; Seyedolali et al. 1997; Bernet and Bassett 2005). Polycrystalline quartz with more than three crystals is rare $(<1 \%)$. (2) Most K-feldspar is altered and frequently replaced by illite (Fig. 4A). Plagioclase, which can be a precursor material for zeolite 
formation, is commonly dissolved and can only be recognized by grain ghosts and small remnants. Therefore, the original abundance of plagioclase might be underestimated. (3) The majority of lithoclasts, especially in samples from McLea Nunatak, are volcanic rock fragments and volcanic glass. Most volcanic fragments are considerably altered or (partially) dissolved and rhyolitic or basaltic clasts can therefore not be differentiated. Sedimentary, plutonic, and metamorphic rock fragments are of only minor importance. (4) Samples from Thumb Point are characterised by higher detrital sheet silicate (mica) content in comparison to samples from the other outcrops.

Petrographic analysis was also used to determine the order in which alteration of framework grains and precipitation or dissolution of authigenic components occurred. We observed in many samples a similar pattern of (1) illite replacement of K-feldspar (Fig. 4A), (2) minor quartz cementation (Fig. 4B), (3) zeolite cementation), plagioclase dissolution, and alteration of volcaniclastic material (Fig. 4B, C, D), (4) dissolution of K-feldspar grains and minor precipitation of albite and K-feldspar in feldspar skeletons (Fig. 4C, D), (5) dissolution of zeolite cement, and calcite and quartz precipitation (Fig. 5). The abundance of the most important authigenic minerals are given in Table 1.

The relation between intergranular volume and cementation is shown in a diagram after Houseknecht (1987) (Fig. 3B), which was originally designed for well-sorted quartz arenites with a primary porosity of $40 \%$. Although only SP-02 is a quartz arenite, this diagram shows the low percentage of primary porosity preserved in the samples, mainly because of pore filling cementation as opposed to compaction.

\section{Electron microprobe analysis}

Highly polished thin sections of eight samples, representing all outcrops, were selected for EMP analysis. These chemical analyses of authigenic phases were focused on clay minerals 
and pore-filling cement, mainly for mineral identification in comparison to XRD analyses. The three main clay mineral types that we identified with EMP analyses were illite, smectite, and chlorite (Table 2). Illite was distinguished by the higher aluminium and potassium content, and smectite and chlorite by higher iron content. Pore-filling and grain-coating chlorites analysed in our samples have relative high $\mathrm{Fe} /[\mathrm{Fe}+\mathrm{Mg}]$ ratios of $0.6-0.9$, and can be subdivided into chamosite and delessite on the basis of their chemical composition. Chemical analysis of pore-filling cement was mainly restricted to zeolite cement, and we identified the two Ca-zeolites heulandite and laumontite as the most common zeolites in our samples (Tables 2 and 3).

\section{XRD analysis}

XRD analyses, also used for mineral identification, are in good agreement with what we found with petrographic and EMP analyses. The results are summarised in Table 4. However, with XRD analysis we found that all samples of McLea Nunatak contain cristobalite in addition to quartz, and also stilbite, a zeolite variety which was not detected in any sample of the other outcrops (Fig. 6).

Illite crystallinity, as an indicator for thermal conditions, was determined for samples from Trio Nunatak and Thumb Point (Fig. 7), but could not be determined for McLea Nunatak samples because the occurrence of smectite in those samples would lead to erroneous results. The sample from Shultz Peak did not contain any illite, and therefore was also excluded.

\section{DISCUSSION}

Following the different analytical results and based on cross-cutting relationships of authigenic precipitates and diagenetic alterations found in the samples, the diagenetic history 
of the Beacon Sandstone in central Victoria Land can be divided into three main stages. These stages include burial diagenesis, contact diagenesis (in the sense of McKinely et al. 2001), and post-contact diagenesis. These three different stages are discussed here in more detail.

\section{Burial diagenesis}

Minor compaction and alteration of K-feldspar by dissolution and replacement with illite are the important diagenetic changes that occurred in the Beacon Sandstone during shallow burial. K-feldspar dissolution in this stage occurs as small etch pits oriented along cleavage planes, which is particularly well developed in samples from Trio Nunatak (Fig. 4A). In the same samples good examples of illite replacement of K-feldspar can be found, which liberates $\mathrm{SiO}_{2}$ on the basis of the following reaction:

$$
\underset{(\mathrm{K} \text {-feldspar) }}{\mathrm{KAlSi} \mathrm{O}_{8}+2 / 3 \mathrm{H}^{+}} \rightarrow \underset{\text { (illite) }}{2 / 3 \mathrm{~K}^{+}}+\underset{\mathrm{KAl}_{3} \mathrm{Si}_{3} \mathrm{O}_{10}(\mathrm{OH})_{2}}{1 / 3}+\underset{\text { (quartz) }}{2 \mathrm{SiO}_{2}(\mathrm{aq})}
$$

Such K-feldspar alteration increases silica activity in pore fluids, which can lead to quartz cementation or provide silica for other reactions. The source of $\mathrm{H}^{+}$for $\mathrm{K}$-feldspar alteration is unknown, but might have been derived from alteration of buried organic material elsewhere and then being introduced by pore fluid flow. Because no significant K-feldspar cementation was observed at this stage, $\mathrm{K}^{+}$-ions must have been exported by pore fluid flow.

Minor quartz cementation occurs as euhedral quartz overgrowth around detrital quartz grains. Because of the overall moderate compaction of the Beacon Sandstone (Fig. 3B), very little silica, if any, may have been derived from pressure solution. More likely silica sources for quartz cementation during burial diagenesis are the K-feldspar-to-illite alterations described above. 


\section{Contact diagenesis}

The Beacon Sandstone does not show macroscopic evidence for contact metamorphism, but displays signs of contact diagenesis, meaning alteration at temperatures between 200$300^{\circ} \mathrm{C}$. A first indicator, even if volumetrically unimportant, is very restricted, secondary quartz cementation, as shown in the CL image in figure 4B. Authigenic quartz usually has low or no luminescence (Zinkernagel 1978) and appears black in panchromatic CL images (Bernet \& Bassett 2005). However, figure 4B shows high luminescent (light grey to white) quartz overgrowth with well-developed sector zoning, which has been described to be hydrothermal quartz (e.g., Onasch \& Venneman 1995). Therefore, it may be possible that minor amounts of hydrothermal quartz were precipitated prior to zeolite cementation at McLea Nunatak (Fig. 4B). McLea Nunatak is also the only outcrop where the silica variety of cristobalite was found in XRD analyses (Fig. 6, Table 4). The cristobalite is certainly not high- $\mathrm{T}$ cristobalite, which forms at temperatures $>1400^{\circ} \mathrm{C}$, but rather metastable, low- $\mathrm{T}$ cristobalite (Deer et al. 1992). Despite the heating caused by the dolerite intrusions, it is impossible that temperature conditions were reached to form high-T cristobalite. It is not known if the generation of minor amounts of possibly hydrothermal quartz overgrowth and low-T cristobalite are in any way related to each other. They were just observed to occur in the same samples.

Much stronger evidence for contact diagenesis comes from the observed zeolite cementation. Zeolites are not common as detrital minerals but occur as authigenic minerals in sandstone (e.g. Hay 1966; Hay and Sheppard 2001). The formation of zeolite is determined partly by temperature conditions (Ghent 1979), but more importantly by the availability of reactive precursor material such as plagioclase, volcanic glass, and volcanic clasts (rhyolitic or basaltic). Therefore, zeolite cements such as heulandite, clinoptilolite, analcime, and laumontite are common in volcaniclastic sandstone (Helmold \& van de Kamp 1984; Hay \& 
Sheppard 2001). Zeolites are formed by a dissolution-precipitation process, where precursor materials are dissolved and zeolite is precipitated. This dissolution-precipitation process also illustrates the importance of the chemical composition of pore fluids (Hay 1966; Surdam \& Boles 1979; Hay \& Sheppard 2001). For example, the silica activity of pore fluids can influence which zeolite is precipitated, because zeolites, such as heulandite and laumontite, have different $\mathrm{Si} / \mathrm{Al}$ ratios (Table 3). Increased silica activity in pore fluids favours heulandite over laumontite formation, and low silica activity favours laumontite according to Murata \& Whitely (1973).

Laumontite can form in volcaniclastic sandstones over a temperature range of $50-100^{\circ} \mathrm{C}$ at the lower limit, and up to $300^{\circ} \mathrm{C}$ at the upper limit (Surdam \& Boles 1979). Therefore, the occurrence of large amounts of laumontite indicates that the Beacon Sandstone was not subjected to temperatures over $300^{\circ} \mathrm{C}$ during contact diagenesis. Surdam \& Boles (1979) also noted that alteration of volcaniclastic material to zeolite can cause a large decrease in primary porosity and permeability in sandstone by pervasive zeolite cementation, similar to what we observed in our samples from McLea Nunatak. Nevertheless, zeolites are not restricted to volcaniclastic sediments but can occur in sandstone deficient of reactive precursor material during deep burial diagenesis. Boles \& Coombs (1977) described zeolites in this respect as indicators for the transition between diagenetic $\left(0-150^{\circ} \mathrm{C}\right)$ and metamorphic $\left(200^{\circ} \mathrm{C}\right.$ and above) conditions.

The question is why do we find zeolite cementation then in the Beacon Sandstone in central Victoria Land? We can consider three different possibilities. First, sufficient zeolite precursor material is available in the sandstone to precipitate zeolite cement in situ. Second, sufficient precursor material is lacking but zeolite cementation is caused by deep burial. Third, hydrothermal fluid flow triggers zeolite cementation independent of precursor material. 
For McLea Nunatak, abundant zeolite precursor material was available, and Ca-zeolites might have formed in situ and/or from hydrothermal fluid associated with the dolerite intrusions. Zeolite formation because of deep burial is unlikely owing to the high intergranular volume preserved in the McLea Nunatak samples, which indicate only shallow burial prior to zeolite cementation (Fig. 3B). Therefore, the most likely scenario is that zeolite precipitation in these samples is related to dolerite intrusions, which provided heat and triggered hydrothermal fluid flow as well as the alteration of plagioclase and volcanic clasts.

Samples from Trio Nunatak, Thumb Point, and Shultz Peak generally lack sufficient zeolite precursor material but still contain Ca-zeolite cement (Tables 1, 2, 3). One possibility is that these samples received part of their zeolite cement from fluid flow during or shortly after dolerite emplacement. This process has at least been suggested by Vavra (1989) and Ballance \& Watters (2002) for zeolite cementation of Beacon Sandstone in other parts of Victoria Land and the Transantarctic Mountains. Furthermore, the phenomenon of thermally induced fluid flow and zeolite cementation has been observed in other geological settings (Dilles et al. 2000; Sheppard \& Hay 2001). Therefore, we suggest that fluid flow triggered by the thermal event of dolerite emplacement is a justified assumption for our samples as well. Unfortunately our data do not allow us to quantify any possible fluid flow driven mass transfer that would be needed to produce zeolite cementation in certain samples. The reason for this is that some of the available precursor materials, such as plagioclase, have been so strongly altered that their original composition cannot be determined, as would be necessary for rigorous mass balance calculations. Nevertheless, we can make an important observation in that it is obvious that porosity and permeability in the Beacon Sandstone were strongly altered and diminished during contact diagenesis, which is quite in contrast to the observations of McKinley et al. (2001) on the Triassic Sherwood Sandstone group in Ireland. 


\section{Evidence for minor contact metamorphism}

One of the aims of this study was to find evidence for the thermal influence of the dolerite intrusions at $180 \mathrm{Ma}$. We found some evidence for contact diagenesis $\left(c .200-300^{\circ} \mathrm{C}\right)$ by widespread, but patchy Ca-zeolite cementation, where laumontite could indicate an upper temperature limit of up to $300^{\circ} \mathrm{C}$. Further evidence for elevated temperatures is given by illite crystallinity calculated for samples from Trio Nunatak and Thumb Point, using the Weber and Weaver indices (Fig. 7). Increased illite crystallinity was observed in samples Trio-53 and Trio-55, which were collected in direct contact with an overlying $>10 \mathrm{~m}$ thick dolerite sill. These samples reached contact metamorphic conditions (Fig. 7). However, sample Trio-51 for example, collected just $5 \mathrm{~m}$ below the sill is well in the diagenetic range of illite crystallinity (Fig. 7). Similar trends were observed in samples from Thumb Point, where even samples in direct contact with intrusions do not show completely metamorphic conditions, but fall into the range of contact diagenesis.

Despite the evidence for thermal overprint, the Beacon Sandstone overall does not show obvious macroscopic contact metamorphic features (Gunn \& Warren 1962; Ballance \& Watters 2002), such as chilled margins or partial melting as it has been described in other settings (Kroiting 1978; Brauckmann \& Füchtbauer 1983). The reason for this may be that these siliciclastic sedimentary rocks were not heated above $200-300^{\circ} \mathrm{C}$ in most parts (Grapes et al. 1974; Korsch 1984). In fact apatite fission-track analysis in other parts of Victoria Land indicate widespread resetting at around $180 \mathrm{Ma}$, which means that temperatures in the order of at least $120^{\circ} \mathrm{C}$ were reached in most of Victoria Land during Gondwana break-up

(Fitzgerald 2002). This provides us with minimum temperature limit. However, ${ }^{40} \mathrm{Ar} /{ }^{39} \mathrm{Ar}$ analysis of detrital mica indicate in general no resetting, which means that ambient temperatures in the Beacon Sandstone did not reach $350^{\circ} \mathrm{C}$ and above (Fitzgerald, pers. com. 
2004). One possible explanation for this is that the Beacon Sandstone was probably saturated with water during the time of intrusion, as argued by Turner (1981).

\section{Post-contact diagenesis}

Zeolites can be dissolved and new mineral phases precipitated when pore fluid conditions change. For example, Helmold \& van de Kamp (1984) demonstrated that Ca-zeolite (heulandite or laumontite) can be altered with $\mathrm{CO}_{2}$ and secondary calcite can be formed in the vicinity, following this reaction:

$$
\begin{aligned}
& \mathrm{CaAl}_{2} \mathrm{Si}_{4} \mathrm{O}_{12} \cdot 4 \mathrm{H}_{2} \mathrm{O}+\mathrm{CO}_{2}+6 \mathrm{H}^{+}=\mathrm{CaCO}_{3}+4 \mathrm{SiO}_{2}+7 \mathrm{H}_{2} \mathrm{O}+2 \mathrm{Al}^{3+} \\
& \text { (laumontite) (calcite) (quartz) }
\end{aligned}
$$

Dissolution of zeolite cement and associated calcite cementation was observed only in a few of our samples, but has also been described by Ballance \& Watters (2002) for Beacon Sandstone from other parts of Victoria Land. We think that occurrence of $\mathrm{CO}_{2}$ in pore fluids may be related to secondary (hydro-) thermal activity in association with the separation of New Zealand and Australia from Antarctica around 96 Ma. Fleming et al. (1993), who studied the alteration of Jurassic basalt flows, postulated such a thermal event. These authors found apophyllites in vacuoles which they dated at $96 \mathrm{Ma}$, using $\mathrm{Rb} / \mathrm{Sr}$ dating. Mohlzahn et al. (1999) made similar observations of basalt alteration, which they associated with renewed hydrothermal activity at c. 96 Ma. However, Ballance \& Watters (2002) postulated that $\mathrm{CO}_{2}$ in pore fluids for Ca-zeolite dissolution and calcite formation might have been derived from the coal measures in the lower part of the Beacon Supergroup. A third possibility for $\mathrm{CO}_{2}$ increase in pore fluids could be the influx of meteoric water, but it has not been documented that significant soil horizons were formed on the Beacon Sandstone or the dolerite and basalt outcrops. Soil horizons could enrich meteoric water with $\mathrm{CO}_{2}$, but we regard this option as less likely for zeolite cement dissolution here. 
No matter which process caused zeolite dissolution, it is a possibility to create secondary porosity. However, A more prominent feature of secondary porosity was observed in samples from McLea Nunatak where K-feldspar grains were dissolved after zeolite cementation (Fig. 4C, D), because no zeolite cement occurs within the Feldspar skeletons, but only occasional albite and K-feldspar cement (Fig. 4C, D).

\section{CONCLUSIONS}

1. The diagenetic history of the Beacon Supergroup can be divided into three main stages of shallow burial diagenesis, contact diagenesis, and post-contact diagenesis. Shallow burial diagenesis is characterised by minor compaction, $\mathrm{K}$-feldspar alteration to illite, and minor quartz cementation. Contact diagenesis, at temperatures of c. $200-300^{\circ} \mathrm{C}$, with abundant zeolite cementation is seen in connection with hydrothermal fluid flow triggered by large dolerite intrusions. Post-contact diagenesis is indicated by K-feldspar clast and Ca-zeolite cement dissolution and minor calcite and quartz precipitation. All these findings are in good agreement with the work of Vavra (1989) and Ballance \& Watters (2002) from other parts of the Beacon Supergroup in Victoria Land.

2. No more than minor contact metamorphism of the Beacon Sandstone was caused by the large dolerite intrusions, and is only detectable in direct contact with the intrusions, as shown by increased illite crystallinity.

3. The overall thermal overprint of the Beacon Sandstone mainly influenced authigenic phases and instable framework grains. Contact diagenesis severely reduced porosity and permeability of the Beacon Sandstone. Minor improvements of porosity and permeability were caused by F-feldspar clast zeolite cement dissolution during post-contact diagenesis leading to secondary porosity. Therefore, our observations on the effect of intrusions on 
sandstone are considerable different from the results of McKinley et al. (2001) on the Triassic Sherwood Sandstone of Northern Ireland.

\section{ACKNOWLEDGEMENTS}

We thank Stefan Wilhelm, who collected the Beacon Supergroup sandstone samples for us during his Antarctic field season in 1992. We acknowledge support from Andreas Kronz, Burkhard Schulz-Dobrick, and Andreas Weinrich during electron microprobe analysis at the Johannes Gutenberg University in Mainz, and from Alexander Fels during SEM analysis in Stuttgart. We are also grateful to, Jim Boles, Warren Dickinson, and Richard Hay for comments on a previous version of this manuscript, and for helpful and constructive reviews by Robert Lynch, Richard Worden, and an anonymous reviewer which greatly improved the manuscript.

\section{REFERENCES}

Bernet M, Bassett K 2005. Provenance Analysis Single-Quartz-Grain SEM-CL/Optical Micrsocopy. Journal of Sedimentary Research 75: 496-505.

Ballance PF, Watters WA 2002. Hydrothermal alteration, contact metamorphism, and authigenesis in Ferrar Supergroup and Beacon Supergroup Rocks, Carapace Nunatak, Allan Hills, and Coombs Hills, Victoria Land, Antarctica. New Zealand Journal of Geology and Geophysics 45: 71-84.

Barrett PJ 1972. Stratigraphy and petrology of the mainly fluvial Permian and Triassic part of the Beacon Supergroup, Breadmore glacier area. In: Adie RJ ed. Antarctic Geology and Geophysics. International Union of Geological Sciences Series B-1: 365-372. 
Barrett PJ 1991. The Devonian to Jurassic Beacon Supergroup of the Transantarctic Mountains and correlatives in other parts of Antarctica. In: Tingey R ed. The geology of Antarctica. Oxford monographs on Geology and Geophysics 17: 680 p.

Boles JR, Coombs SD 1975. Mineral reactions in zeolitic Triassic tuff, Hokonui Hills, New Zealand. Geological Society of America Bulletin 86: 163-173.

Boles JR, Coombs SD 1977. Zeolite facies alteration of sandstones in the Southland syncline, New Zealand. American Journal of Science 277: 982-1012.

Brauckmann FJ, Füchtbauer H 1983. Alterations of Cretaceous siltstones and sandstones near basalt contacts. Sedimentary Geology 35: 193-213.

Collinson JW, Pennington DC 1986. Stratigraphy and Petrology of Permian and Triassic fluvial deposits in northern Victoria Land, Antarctica. Antarctic Research Series 46: 211-242.

Deer WA, Howie RA, Zussman J 1992. An introduction to the rock-forming minerals. 2nd ed. London, Longman Scientific and Technical. XXX p.

Dilles JH, Barton MD, Johnson DA, Proffett JM, Einaudi MT 2000. Part 1 Contrasting styles of intrusion-associated hydrothermal systems. Guidebook Series Society of Economic Geologists 32: 162 p. 
Fitzgerald PG 1992. The Transantarctic Mountains of southern Victoria Land: The application of apatite fission track analysis to a rift shoulder uplift. Tectonics 11: 634-662.

Fitzgerald PG 2002. Tectonics and landscape evolution of the Antarctic plate since the breakup of Gondwana, with an emphasis on the West Antarctic Rift System and the Transantarctic Mountains. Royal Society of New Zealand Bulletin 35: 453-469.

Fleming TH, Foland KA, Elliot DH 1993. Direct dating of mid-Cretaceous alteration of the Kirkpatrick Basalt in north Victoria Land: ${ }^{40} \mathrm{Ar} /{ }^{39} \mathrm{Ar}$ and $\mathrm{Rb} / \mathrm{Sr}$ ages for apophyllites. Antarctic Journal of the United States 28: 38-40.

Fleming TH, Heimann A, Foland KA, Elliot DH 1997. ${ }^{40} \mathrm{Ar} /{ }^{39} \mathrm{Ar}$ geochronology of Ferrar Dolerite sills from the Transantarctic Mountains, Antarctica: Implications for the age and origin of the Ferrar magmatic province. Geological Society of America Bulletin 109: 533546.

Foland KA, Fleming TH, Heimann A, Elliot DH 1993. Potassium-argon dating of fine grained basalts with massive Ar loss: Application of the ${ }^{40} \mathrm{Ar} /{ }^{39} \mathrm{Ar}$ technique to plagioclase and glass from the Kirkpatrick Basalt, Antarctica. Chemical Geology (Isotope Geoscience Section) 107: 173-190.

Ghent ED 1979. Problems in zeolite facies geothermometry, geobarometry and fluid compositions. In: Scholle PA, Schluger PR ed. Aspects of diagenesis. Society of Economic Paleontologists and Mineralogists Special Publication 26: 81-87. 
Grapes RH, Reid DL, McPherson JG 1974. Shallow dolorite intrusion and phreatic eruption in the Allan Hills region, Antarctica. New Zealand Journal of Geology and Geophysics 17: $563-577$.

Gunn BM, Warren G 1962. Geology of Victoria Land between Mawson and Mulock Glaciers, Antarctica. New Zealand Geological Survey Bulletin 71: 157 p.

Hay RL 1966. Zeolites and zeolitic reactions in sedimentary rocks. Geological Society of America Special Publication 85: 130 p.

Hay RL, Sheppard RA 2001. Occurrence of zeolites in sedimentary rocks: An Overview. In: Bish DL, Ming DW ed. Natural Zeolites. Reviews in Mineralogy and Geochemistry 45: 217234.

Helmold KP, van de Kamp PC 1984. Diagenetic mineralogy and controls on albitization and laumontite formation in Paleogene arkoses, Santa Ynez Mountains, California. In: McDonald DA, Surdam RC ed. Clastic diagenesis. American Association of Petroleum Geologists Memoir 37: 239-276.

Houseknecht DW 1987. Assessing the relative importance of compaction processes and cementation to the reduction of primary porosity in sandstones. Journal of Sedimentary Petrology 58: 228-246.

Korsch RJ 1984. The structure of Shapeless Mountain, Antarctica, and its relation to Jurassic igneous activity. New Zealand Journal of Geology and Geophysics 27: 487-504. 
Kroiting S 1978. Die Blaue Kuppe bei Eschwege. Der Aufschluß Sonderband 28: 237-247.

McBride EF 1963. A classification of common sandstone. Journal of Sedimentary Petrology 33: 664-669.

McKinley JM, Worden RH, Ruffell AH 2001. Contact diagenesis: The effects of an intrusion on reservoir quality in the Triassic Sherwood sandstone group, Northern Ireland. Journal of Sedimentary Research 71: 484-495.

Miller BE, Ghent ED 1973. Laumontite and barian-strontian heulandite from Blairmore Group (Cretaceous), Alberta. Canadian Mineralogist 12: 188-192.

Molzahn M, Wörner G, Henjes-Kunst F, Rocholl A 1999. Constraints on the Cretaceous thermal event in the Transantarctic Mountains from alteration processes in Ferrar flood basalts. Global and Planetary Change 23: 45-60.

Murata KJ, Whitely KR 1973. Zeolites in the Miocene Briones Sandstone and related formations of the central coast ranges, California. Journal of Research, United States Geological Survey 1: 255-265.

Onasch CM, Vennemann TW 1995. Disequilibrium partioning of oxygen isotopes associated with sector zoning in quartz. Geology 23: 1103-1106. 
Reed SJB 1997. Electron Microprobe Analysis. 2nd ed. Edinburgh, Cambridge University Press. 344 p.

Remy RR 1994. Porosity reduction and major controls on diagenesis of CretaceousPaleocene volcaniclastic and arkosic sandstone, Middle Park Basin, Colorado. Journal of Sedimentary Petrology A64: 797-806.

Seyedolali A, Krinsley DH, Boggs S, O’Hara PF, Dypvik H, Goles GG 1997. Provenance interpretation of quartz by scanning electron microscope-cathodoluminescence fabric analysis. Geology 25: 787-790.

Sheppard RA, Hay RL 2001: Formation of zeolites in open hydrologic systems: An Overview. In: Bish DL, Ming DW ed. Natural Zeolites. Reviews in Mineralogy and Geochemistry 45: 261-275.

Sprunt ES, Nur A 1979. Microcracking and healing in granites: New evidence from cathodeluminescence. Science 205: 495-497.

Surdam RC, Boles JR 1979. Diagenesis of volcanic sandstones. In: Scholle PA, Schluger PR ed. Aspects of diagenesis. Society of Economic Paleontologists and Mineralogists Special Publication 26: 227-242.

Turner FJ 1981. Metamorphic petrology. 2nd ed. New York, McGraw-Hill Book Co. 
Vavra CL 1989. Mineral reactions and controls on zeolite-facies alteration in sandstone of the central Transantarctic Mountains, Antarctica. Journal of Sedimentary Petrology 59: 688-703.

Vavra CL, Stanley KO, Collinson JW 1979. Sedimentary petrology of the Triassic Fremouw Formation, central Transantarctic Mountains. Antarctic Journal of the United States 14: 2830.

Weaver CE 1960. Possible use of clay minerals in search of oil. American Association of Petroleum Geologists Bulletin 44: 1505-1518.

Weber K 1972. Kristallinität des Illits in Tonschiefern und andere Kriterien schwacher Metamorphose im nordöstlichen Rheinischen Schiefergebirge. Neues Jahrbuch für Geologie und Paläontologie, Abhandlungen 141: 333-363.

Wilhelm S 1994. Geochemische und quantitativ petrographische Untersuchungen (Kristallgrößenverteilung) an Ferrar-Sills und Kirkpatrick-Flows, Victoria Land, Antarktis [Unpublished Masters thesis]. Johannes-Gutenberg Universität Mainz, Germany. 172 p.

Wilson M 1989. Igenous Petrogenesis, a global tectonic approach. Chapman and Hall, New York. 466 p.

Zinkernagel U 1978. Cathodoluminescence of quartz and its application to sandstone petrology. Contributions to Sedimentology 8: $69 \mathrm{p}$. 


\section{FIGURES CAPTIONS}

Fig. 1 Sample locations of Trio Nunatak, McLea Nunatak, Thumb Point, and Shultz Peak in Victoria Land, Antarctica (map after Wilhelm 1994).

Fig. 2 Simplified stratigraphy of the Beacon Supergroup in Victoria Land, Antarctica, after Barrett (1972) and Collinson \& Pennington (1986).

Fig. 3 A Classification after McBride (1963) of Beacon Supergroup sandstone on the basis of 300400 point-counts using traditional point-counting techniques. B Intergranular volume versus cement diagram after Houseknecht (1987), showing the relatively high percentage of intergranular volume preserved in most sandstones of the Beacon Supergroup, indicating shallow burial prior to dolerite intrusions, contact diagenesis and associated zeolite cementation.

Fig. 4 A Illite replacement of K-feldspar and dissolution pits in K-feldspar. (Backscatter electron image (EMP) of a sample from Trio Nunatak. B Cathodoluminescence image of quartz grains with euhedral quartz overgrowth, which displays well developed sector zoning, commonly found in hydrothermal quartz (Onasch \& Vennemann 1995). Pore-filling laumontite cement appears black. Sample from McLea Nunatak. C Feldspar skeletons (secondary porosity) of which only one is filled by K-feldspar and albite precipitation. Pervasive zeolite cementation, in one case filling in the outline of a former clast (plagioclase ?) in the upper right of the picture. Sample from McLea Nunatak. D Skeletal remnants of former feldspar clasts surrounded by zeolite cement. This indicates that this phase of K-feldspar dissolution occurred after zeolite cementation. The large clast in the centre is cemented with K-feldspar and albite. Sample from McLea Nunatak. Abbreviations: Ab = albite, K-fsp $=\mathrm{K}$-feldspar, $\mathrm{Lmt}=$ laumontite. 
Fig. 5 Simplified paragenesis of the three different diagenetic stages of $\mathbf{A}$ burial diagenesis, $\mathbf{B}$ contact diagenesis, and C post-contact diagenesis. Primary porosity was reduced by precipitation of authigenic phases (e.g. illite, quartz, zeolite, and calcite) and secondary porosity was created by dissolution of framework grains (e.g. K-feldspar) and authigenic zeolite cement. Contact diagenesis is defined to occur in connection with dolerite intrusions (after McKinley et al. 2001). Regional heating in association with the basalt intrusions is shown by widespread resetting of apatite fission-track ages $\left(120^{\circ} \mathrm{C}\right.$ or above) to c. 180 Ma throughout Victoria Land (Fitzgerald 2003).

Fig. 6 Examples of XRD analysis of samples from Trio Nunatak and McLea Nunatak. McLea Nunatak is the only location where cristobalite and stilbite were identified with XRD. Abbreviations: $\mathrm{Qtz}=$ quartz, $\mathrm{Or}=$ othroclase, $\mathrm{Chl}=$ chlorite, $\mathrm{Stb}=$ stilbite, $\mathrm{Hul}=$ heulandite, $\mathrm{Ab}=$ albite.

Fig. 7 Illite crystallinity can be used as an indicator of diagenesis and metamorphism. This diagram is based on the comparison between the Weaver (1960) and Weber (1972) illite crystallinity indices and sample distance to dolerite intrusion. See text for details. Metamorphic conditions are barely reached even in samples in direct contact with the dolerite intrusions. Contact-diagenetic conditions, however, can be observed up to 20 meters away from the contact. 
Table 1 Location and petrographic overview of Beacon Supergroup sandstone samples.

\begin{tabular}{|c|c|c|c|c|c|c|c|c|c|c|c|c|}
\hline $\begin{array}{l}\text { Outcrop and } \\
\text { Samples }\end{array}$ & $\begin{array}{l}\text { Distance } \\
\text { to sill } \\
\text { (m) }\end{array}$ & $\begin{array}{l}\text { Mean grain } \\
\text { size }(\mathrm{mm})\end{array}$ & Sorting & $\begin{array}{c}\mathrm{Q} \\
(\%)\end{array}$ & $\begin{array}{l}\mathrm{F} \\
(\%)\end{array}$ & $\begin{array}{c}\mathrm{L} \\
(\%)\end{array}$ & $\begin{array}{c}\text { Porosity } \\
(\%)\end{array}$ & $\begin{array}{c}\text { Calcite } \\
\text { cement } \\
(\%)\end{array}$ & $\begin{array}{c}\text { Quartz } \\
\text { cement } \\
(\%)\end{array}$ & $\begin{array}{c}\text { Zeolite } \\
\text { cement } \\
(\%)\end{array}$ & $\begin{array}{c}\text { authigenic } \\
\text { Chlorite } \\
(\%)\end{array}$ & $\begin{array}{c}\text { authigenic } \\
\text { Illite } \\
(\%)\end{array}$ \\
\hline \multicolumn{13}{|l|}{ Trio Nunatak } \\
\hline Trio-50 & 0.1 & 0.24 & moderate & 59.8 & 21.2 & 19.0 & 0.0 & 11.2 & 9.84 & & 5.46 & 1.09 \\
\hline Trio-51 & 5.0 & 0.39 & poor & 64.1 & 12.7 & 23.2 & 1.5 & & 7.60 & & 2.63 & 22.20 \\
\hline Trio-53 & 0.0 & 0.25 & well & 90.1 & 2.1 & 7.8 & 3.5 & 2.54 & 7.11 & 7.11 & & 0.25 \\
\hline Trio-54 & 1.5 & 0.30 & moderate & 71.4 & 14 & 14.6 & 0.3 & & 4.45 & & 5.93 & 7.72 \\
\hline Trio-55 & 0.1 & 0.55 & poorly & 80.1 & 16.4 & 3.5 & 1.1 & 6.33 & 7.59 & 1.77 & 1.52 & 4.55 \\
\hline Trio-56 & 3.0 & 0.35 & $\begin{array}{l}\text { moderate - } \\
\text { well }\end{array}$ & 72.4 & 12 & 15.6 & 0.0 & 7.03 & 2.18 & 0.73 & 9.71 & 4.85 \\
\hline \multicolumn{13}{|l|}{ McLea Nunatak } \\
\hline ML-01 & 10 & 0.27 & moderate & 42.9 & 23.8 & 33.3 & 0.0 & & 2.50 & 23.75 & 2.25 & 1.50 \\
\hline ML-02 & 20 & 0.27 & well & 36.0 & 21.0 & 43.0 & 1.5 & & 2.33 & 22.15 & 2.92 & 3.21 \\
\hline ML-04 & 10 & 0.54 & moderate & 72.6 & 14.6 & 12.8 & 15.1 & & 12.04 & 10.08 & 1.80 & 0.28 \\
\hline ML-05 & 0 & 0.49 & Moderate & 70.5 & 21.2 & 8.3 & 6.0 & 3.71 & 4.50 & 12.60 & & 6.60 \\
\hline \multicolumn{13}{|l|}{ Thumb Point } \\
\hline TPB-01 & 20 & 0.18 & moderate & 71.7 & 9.1 & 19.2 & 1.1 & & 5.07 & 3.73 & 1.33 & 4.53 \\
\hline TPB-02 & 22 & 0.16 & $\begin{array}{l}\text { moderate - } \\
\text { well }\end{array}$ & 71.2 & 0 & 28.8 & 0.5 & & 3.72 & & 2.93 & 1.60 \\
\hline ТРВ-03 & 24 & 0.16 & moderate & 84.2 & 2.2 & 13.6 & 0.0 & & 3.40 & 0.85 & 1.92 & 1.42 \\
\hline ТРВ-04 & $0.0^{1}$ & 0.33 & moderate & 81.1 & 0.8 & 18.1 & 0.3 & 1.28 & 5.13 & & & 2.56 \\
\hline TPB-06 & 0.0 & 0.57 & poor & 85.7 & 1.7 & 12.6 & 0.7 & & 3.31 & & & \\
\hline ТРВ-07 & 0.0 & 0.34 & poor & 78.8 & 12.1 & 9.1 & 0.3 & & 4.09 & 0.58 & & \\
\hline \multicolumn{13}{|l|}{ Shultz Peak } \\
\hline SP-02 & unknown & 0.15 & well & 97.2 & 1.2 & 1.6 & 8.9 & & 11.49 & 5.75 & & \\
\hline
\end{tabular}

Distances to dolerite sills are on the basis of approximate measurements. ${ }^{1}$ Sample TPB-04 was collected in direct contact with a post-Jurassic andesite dike. QFL data are normalised to $100 \%$ (after McBride 1963). Porosity is intergranular porosity, not including secondary porosity by dissolution of grains. 
Table 2 Representative electron microprobe analyses of clay minerals and zeolite cement.

\begin{tabular}{|c|c|c|c|c|c|c|c|c|c|c|}
\hline Weight \% & Trio-55 & Trio-53 & Trio-55 & ML-02 & ML-04 & ML-05 & ML-05 & ТPB 03 & ТРВ 06 & TPB 06 \\
\hline & Illite & Illite & Chlorite & Smectite & Smectite & Smectite & Illite & Chlorite & Chlorite & Chlorite \\
\hline $\mathrm{SiO}_{2}$ & 45.54 & 50.71 & 23.48 & 42.04 & 45.75 & 34.73 & 44.17 & 25.50 & 28.90 & 26.05 \\
\hline $\mathrm{TiO}_{2}$ & 0.01 & 0.12 & 0.07 & 0.76 & 3.93 & 0.02 & 0.09 & 0.14 & 0.04 & 0.07 \\
\hline $\mathrm{Al}_{2} \mathrm{O}_{3}$ & 32.40 & 33.93 & 19.02 & 11.11 & 22.27 & 32.22 & 30.16 & 17.82 & 18.00 & 19.00 \\
\hline $\mathrm{Cr}_{2} \mathrm{O}_{3}$ & 0.00 & 0.07 & 0.00 & 0.05 & 0.04 & 0.03 & 0.00 & 0.00 & 0.00 & 0.00 \\
\hline $\mathrm{Fe}_{2} \mathrm{O}_{3}$ & 1.43 & 0.86 & 36.21 & 18.33 & 6.41 & 16.21 & 1.72 & 36.18 & 31.83 & 40.50 \\
\hline $\mathrm{MgO}$ & 0.31 & 0.61 & 3.13 & 5.20 & 1.28 & 0.19 & 0.78 & 6.41 & 3.07 & 2.77 \\
\hline $\mathrm{MnO}$ & 0.03 & 0.02 & 1.21 & 0.31 & 0.08 & 0.19 & 0.04 & 0.36 & 0.08 & 0.24 \\
\hline $\mathrm{CaO}$ & 0.12 & 0.77 & 0.19 & 2.38 & 0.52 & 0.09 & 0.72 & 0.64 & 0.69 & 0.20 \\
\hline $\mathrm{Na}_{2} \mathrm{O}$ & 0.30 & 0.33 & 0.06 & 0.27 & 0.22 & 1.90 & 0.24 & 0.12 & 0.43 & 0.03 \\
\hline $\mathrm{K}_{2} \mathrm{O}$ & 8.94 & 7.27 & 0.02 & 1.32 & 1.59 & 0.03 & 6.24 & 0.06 & 0.80 & 0.02 \\
\hline Total & 89.08 & 94.69 & 83.39 & 81.77 & 82.09 & 85.61 & 84.16 & 87.23 & 83.84 & 88.88 \\
\hline \multirow[t]{2}{*}{ Weight $\%$} & Trio-53 & Trio-53 & ML-02 & ML-04 & ML-04 & ML-05 & ML-05 & ТРВ 03 & ТРВ 03 & SP-02 \\
\hline & Hul & Hul & Hul & Hul & Lmt & Lmt & Lmt & Hul & Hul & $\mathrm{Lmt}$ \\
\hline $\mathrm{SiO}_{2}$ & 60.54 & 58.43 & 60.03 & 60.34 & 53.47 & 52.64 & 51.96 & 55.07 & 58.57 & 53.01 \\
\hline $\mathrm{TiO}_{2}$ & 0.00 & 0.04 & 0.00 & 0.00 & 0.010 & 0.04 & 0.02 & 0.08 & 0.06 & 0.00 \\
\hline $\mathrm{Al}_{2} \mathrm{O}_{3}$ & 14.78 & 14.47 & 14.03 & 15.88 & 21.33 & 21.70 & 21.69 & 14.52 & 15.12 & 21.20 \\
\hline $\mathrm{Cr}_{2} \mathrm{O}_{3}$ & 0.00 & 0.00 & 0.01 & 0.03 & 0.00 & 0.00 & 0.00 & 0.00 & 0.000 & 0.00 \\
\hline $\mathrm{Fe}_{2} \mathrm{O}_{3}$ & 0.06 & 0.04 & 0.02 & 0.00 & 0.03 & 0.07 & 0.04 & 0.16 & 0.20 & 0.05 \\
\hline $\mathrm{MgO}$ & 0.05 & 0.04 & 0.03 & 0.00 & 0.00 & 0.02 & 0.00 & 0.06 & 0.07 & 0.02 \\
\hline $\mathrm{MnO}$ & 0.00 & 0.00 & 0.00 & 0.00 & 0.01 & 0.02 & 0.03 & 0.03 & 0.03 & 0.06 \\
\hline $\mathrm{CaO}$ & 7.18 & 7.11 & 8.13 & 7.91 & 11.23 & 10.96 & 11.57 & 4.34 & 4.91 & 10.92 \\
\hline $\mathrm{Na}_{2} \mathrm{O}$ & 0.40 & 0.33 & 0.20 & 0.50 & 0.17 & 0.13 & 0.03 & 0.75 & 0.62 & 0.20 \\
\hline $\mathrm{K}_{2} \mathrm{O}$ & 00.21 & 0.21 & 0.02 & 0.06 & 0.31 & 0.37 & 0.05 & 0.29 & 0.32 & 0.43 \\
\hline Total & 83.22 & 80.67 & 82.47 & 84.72 & 86.56 & 85.95 & 85.39 & 75.30 & 79.90 & 85.89 \\
\hline $\mathrm{H}_{2} \mathrm{O}$ & 16.78 & 19.33 & 17.53 & 15.28 & 13.44 & 14.05 & 14.61 & 24.70 & 20.10 & 14.11 \\
\hline
\end{tabular}

The relative low totals are a result of analysing very fine grained material. $\mathrm{Fe}_{2} \mathrm{O}_{3}$ values for chlorite also contain FeO. Hul $=$

heulandite, $\mathrm{Lmt}=$ laumontite. Because microprobe analyses do not provide $\mathrm{H}_{2} \mathrm{O}$ measurements, water content is calculated by subtracting total oxides from 100\% (after Miller \& Ghent 1973). 
Table $3 \mathrm{Si} / \mathrm{Al}$ ratios in zeolite cement based on electron microprobe analyses

\begin{tabular}{|c|c|c|c|c|c|c|c|c|c|c|c|c|c|}
\hline & Trio-53 & Trio-53 & ML-02 & ML-02 & ML-04 & ML-04 & ML-05 & ML-05 & TPB 03 & ТPB 03 & ТРВ 03 & SP-02 & SP-02 \\
\hline & Hul & Hul & Hul & Hul & Hul & Lmt & $\mathrm{Lmt}$ & $\mathrm{Lmt}$ & Hul & Hul & Hul & Lmt & $\mathrm{Lmt}$ \\
\hline $\mathrm{Si}$ & 28.40 & 28.80 & 27.65 & 27.72 & 27.79 & 4.11 & 4.07 & 4.14 & 30.52 & 30.25 & 30.19 & 4.13 & 4.09 \\
\hline $\mathrm{Al}$ & 7.61 & 7.20 & 8.35 & 8.28 & 8.21 & 1.89 & 1.93 & 1.86 & 5.48 & 5.65 & 5.81 & 1.87 & 1.91 \\
\hline $\mathrm{Ca}$ & 3.56 & 3.53 & 4.08 & 4.00 & 3.87 & 0.92 & 0.96 & 0.9 & 2.45 & 2.36 & 2.52 & 0.9 & 0.93 \\
\hline $\mathrm{Na}$ & 0.36 & 0.06 & 0.18 & 0.27 & 0.44 & 0.03 & 0.00 & 0.02 & 0.39 & 0.74 & 0.57 & 0.03 & 0.02 \\
\hline $\mathrm{K}$ & 0.12 & 0.08 & 0.01 & 0.01 & 0.03 & 0.03 & 0.00 & 0.04 & 0.18 & 0.19 & 0.19 & 0.04 & 0.03 \\
\hline $\mathrm{Si} / \mathrm{Al}$ & 3.73 & 4.00 & 3.31 & 3.35 & 3.38 & 2.17 & 2.11 & 2.23 & 5.57 & 5.35 & 5.20 & 2.21 & 2.14 \\
\hline
\end{tabular}

$\mathrm{Hul}=$ heulandite, $\mathrm{Lmt}=$ laumontite. Heulandite is normalised to 72 oxygen, following the general chemical formula $\left(\mathrm{Ca}, \mathrm{Na}_{2}, \mathrm{~K}_{2}\right)_{4}\left[\mathrm{Al}_{8} \mathrm{Si}_{28} \mathrm{O}_{72}\right.$

] $24 \mathrm{H}_{2} \mathrm{O}$ (Miller \& Ghent 1973). Laumontite is normalised to the general formula $\mathrm{Ca}_{\mathrm{x}}\left(\mathrm{Na}_{2} \mathrm{~K}\right)_{\mathrm{y}} \mathrm{Al}_{2 \mathrm{x}+\mathrm{y}} \mathrm{Si}_{6-(2 \mathrm{x}+\mathrm{y})} \mathrm{O}_{12}{ }^{\bullet} 4 \mathrm{H}_{2} \mathrm{O}\left(\mathrm{Miller}_{2} \& \mathrm{Ghent}^{1973}\right)$.

An additional characteristic to differentiate between heulandite and laumontite is their Si/Al ratio of 3-4 and 2-3, respectively (Murata \& Whitely 1973). 
Table 4 Mineral identification with XRD whole rock analysis $(<63 \mu \mathrm{m}$ and $<2 \mu \mathrm{m})$.

\begin{tabular}{lllllllllll}
\hline Sample & Quartz & \multicolumn{2}{l}{ Feldspar } & Mica & \multicolumn{3}{c}{ Clays } & & \multicolumn{2}{c}{ Zeolites } \\
\hline Trio-50 & Qtz & Ab & & & Ill & Mnt & Chl & Lmt & \\
Trio-51 & Qtz & Ab & Kfs & & Ill & & Chl & & \\
Trio-53 & Qtz & Ab & Kfs & Ms & Ill & & & Lmt & Hul \\
Trio-54 & Qtz & Ab & Kfs & Ms & Ill & & Chl & & \\
Trio-55 & Qtz & & Kfs & Ms & Ill & & Chl & & \\
Trio-56 & Qtz & & Kfs & Ms & Ill & & Chl & & & \\
ML-01 & Qtz/Crs & Ab & Kfs & & Ill & Mnt & Chl & & Hul & Stb \\
ML-02 & Qtz/Crs & Ab & Kfs & & Ill & Mnt & & Lmt & Hul & Stb \\
ML-04 & Qtz/Crs & Ab & Kfs & & Ill & & & Lmt & Hul & Stb \\
ML-05 & Qtz/Crs & Ab & Kfs & & Ill & & & Lmt & Hul & \\
TPB-01 & Qtz & Ab & Kfs & Ms & Ill & & Chl & Lmt & & \\
TPB-02 & Qtz & & Kfs & Ms & Ill & & Chl & & & Hul \\
TPB-03 & Qtz & & Kfs & Ms & Ill & & Chl & & & \\
TPB-04 & Qtz & & & Ms & Ill & & Chl & & & \\
TPB-06 & Qtz & & & Ms & Ill & & Chl & & \\
TPB-07 & Qtz & Ab & Kfs & & Ill & & Chl & Lmt & & \\
SP-02 & Qtz & & & & & & & Lmt & & \\
\hline
\end{tabular}

$\mathrm{Qtz}=$ quartz, $\mathrm{Crs}=$ cristobalite, $\mathrm{Ab}=$ albite, $\mathrm{Kfs}=\mathrm{K}$-feldspar, $\mathrm{Ms}=$ muscovite, $\mathrm{Ill}=$ illite, $\mathrm{Mnt}=$ montmorillonite, $\mathrm{Chl}=$ chlorite, $\mathrm{Lmt}=$ laumontite, $\mathrm{Hul}=$ heulandite, $\mathrm{Stb}$ $=$ stilbite. 


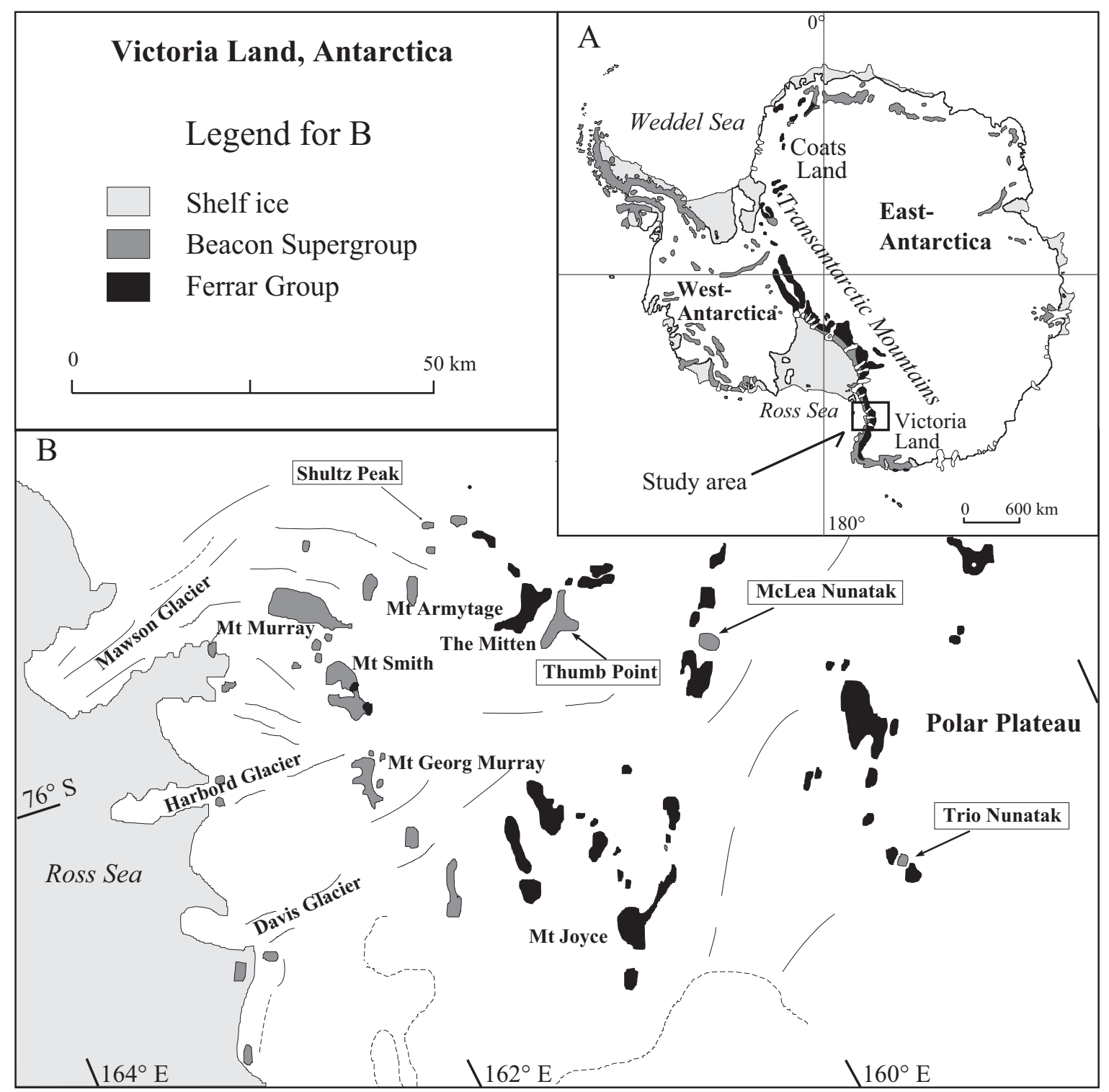

Figure 1 Bernet and Gaupp 


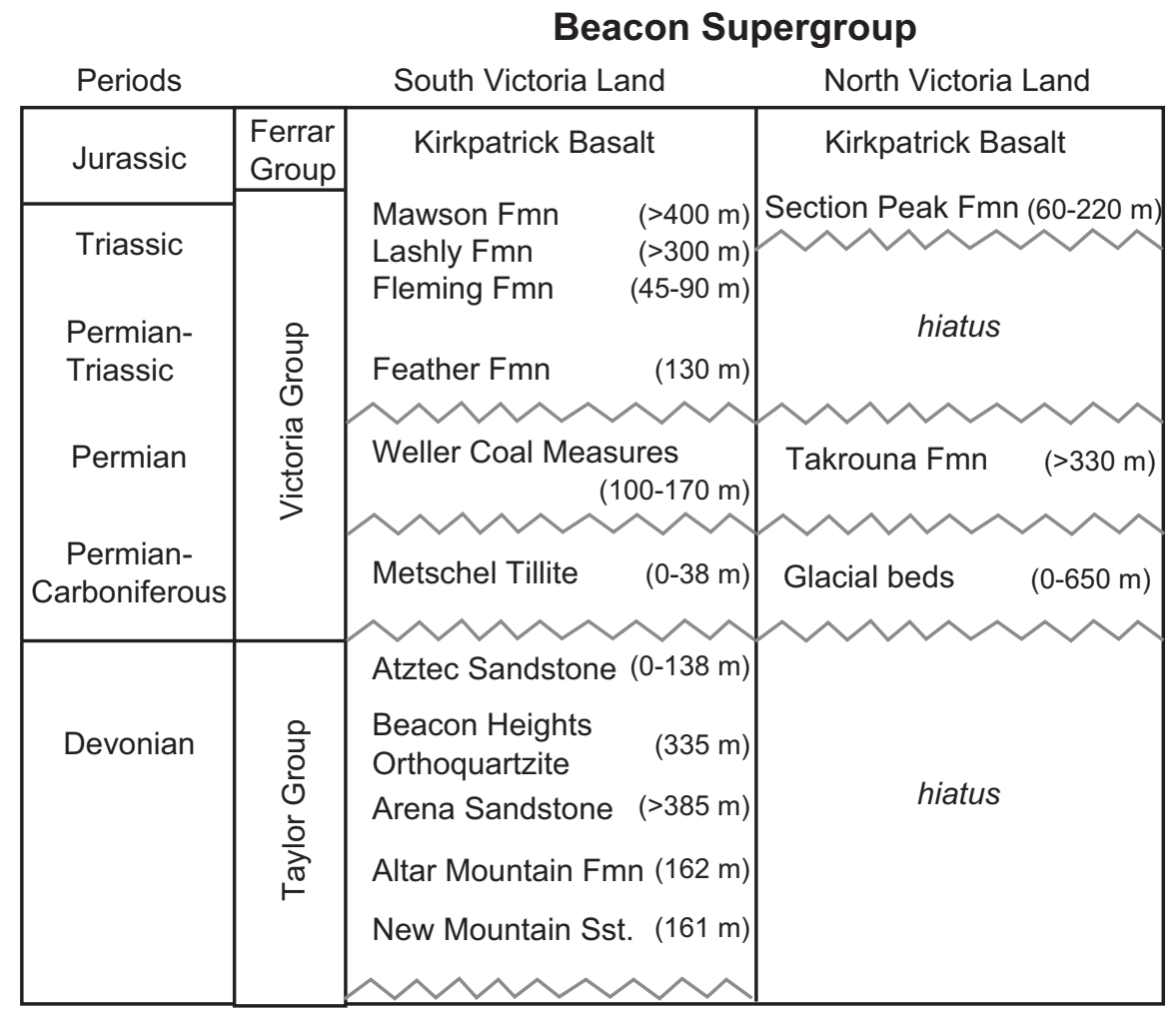

Figure 2 Bernet and Gaupp 

A
Quartz
B

- Trio Nunatak

- McLea Nunatak

$\triangle$ Shultz Peak

$\diamond$ Thumb Point
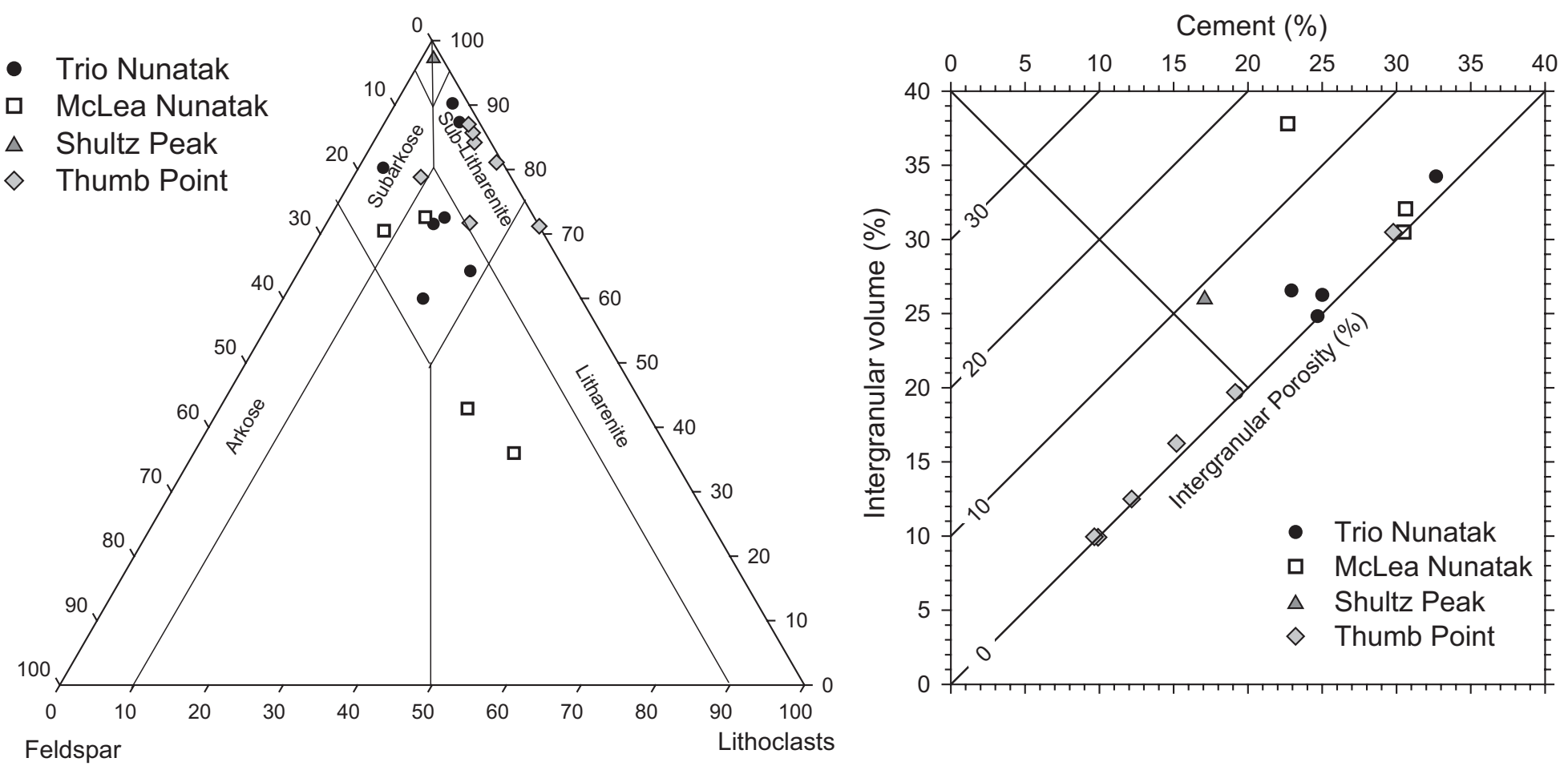

Fig.3 Bernet and Gaupp 


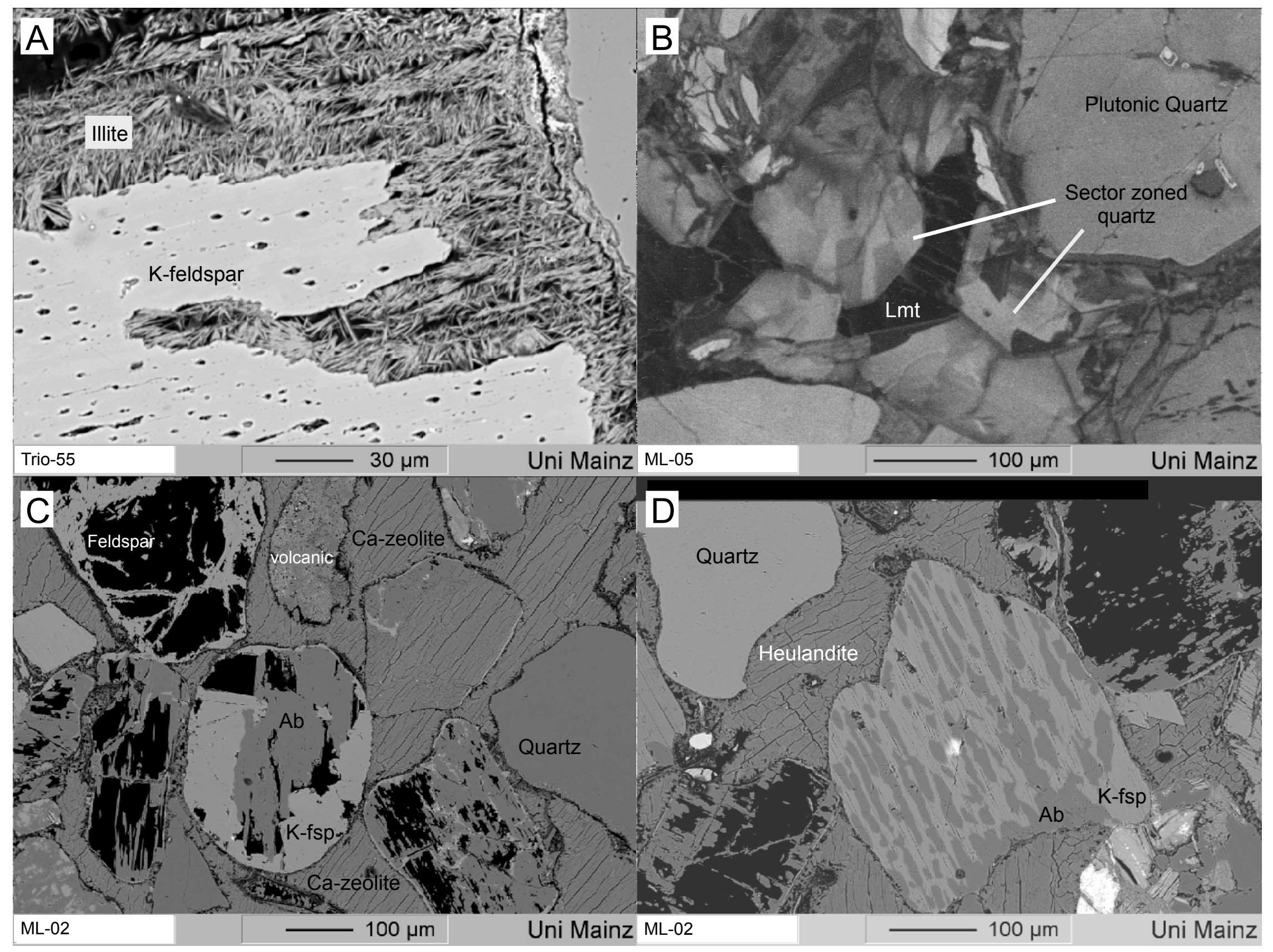




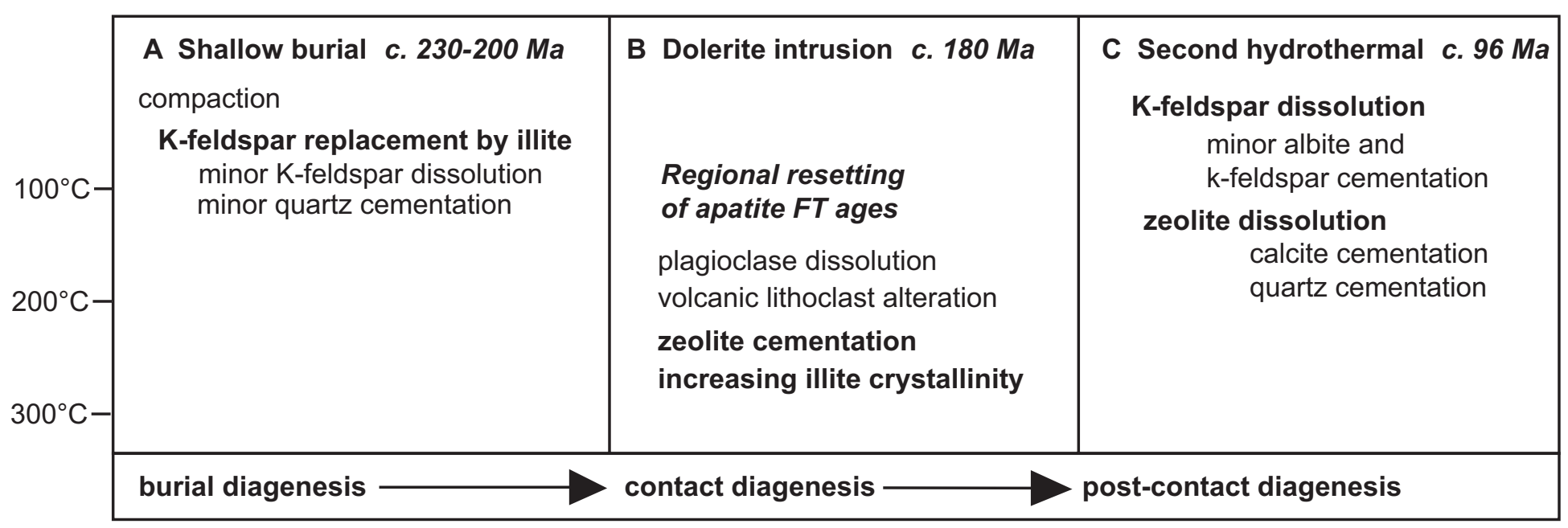

Fig 5 Bernet and Gaupp 


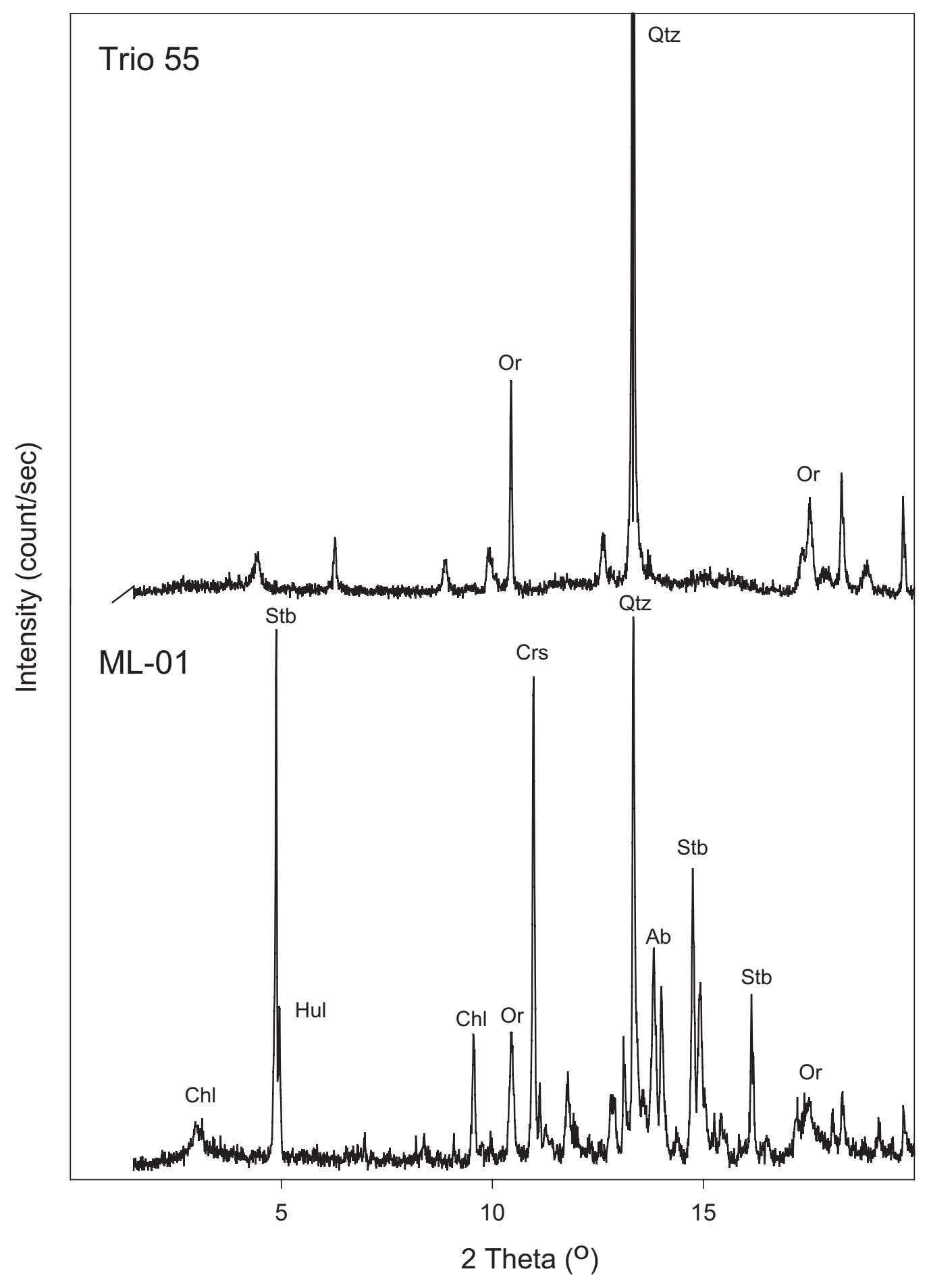

Fig. 6 Bernet and Gaupp 


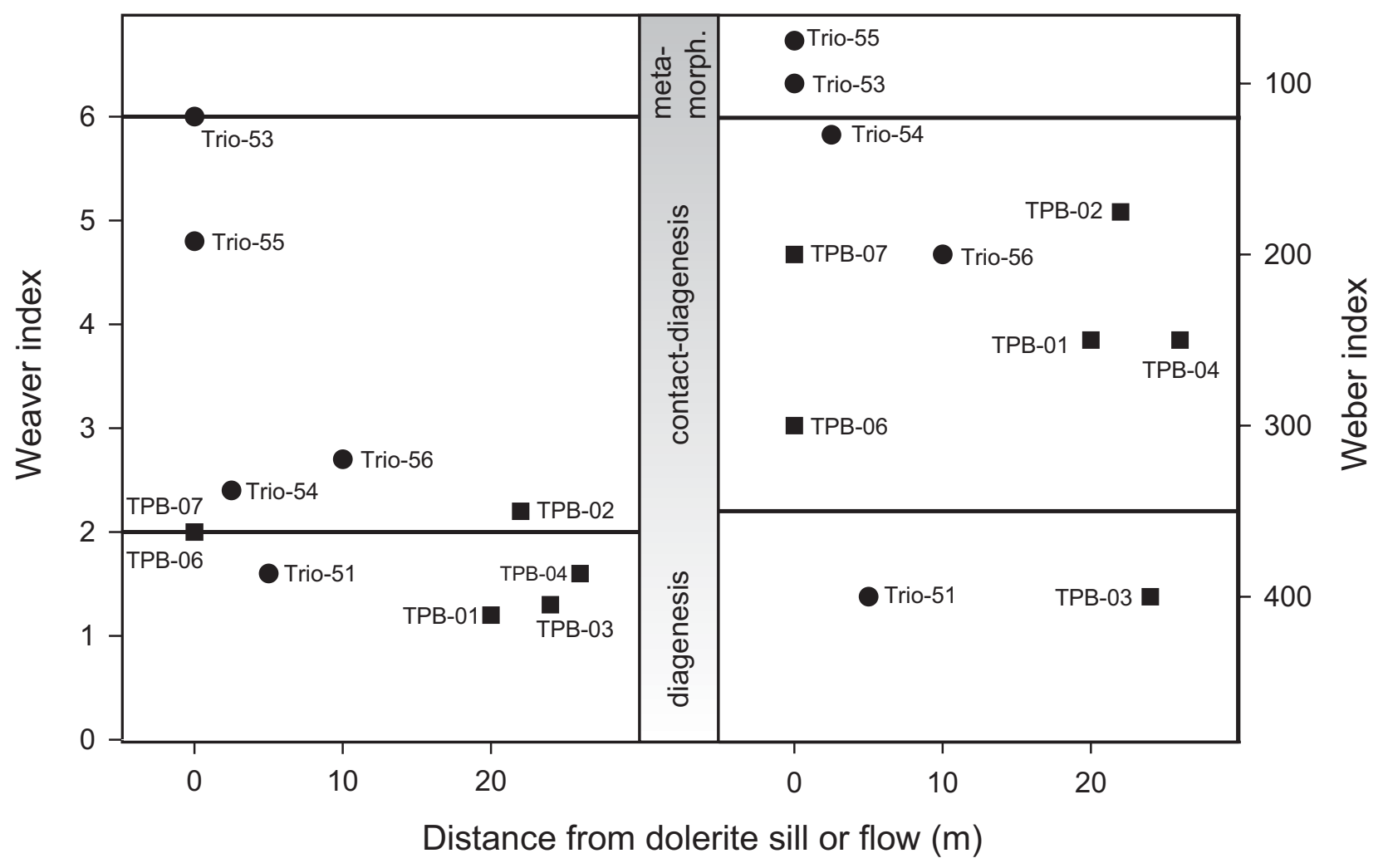

Fig. 7 Bernet and Gaupp 